\title{
Irrigation Scheduling to Promote Corn Productivity in Central Alabama
}

\author{
Jose F. Da Cunha Leme Filho ${ }^{1}$, Brenda V. Ortiz ${ }^{2}$, Damianos Damianidis ${ }^{3}$, Kipling S. Balkcom ${ }^{4}$, Mark Dougherty ${ }^{5}$ \\ $\&$ Thorsten Knappenberger ${ }^{2}$ \\ ${ }^{1}$ School of Plant \& Environmental Sciences, Virginia Polytechnic Institute \& State University, Blacksburg, VA, \\ USA \\ ${ }^{2}$ Department of Crop, Soil and Environmental Sciences, Auburn University, Auburn, AL, USA \\ ${ }^{3}$ Soil, Water and Crop Management Group, EEA Oliveros-INTA, Oliveros, Pcia, Santa Fe, Argentina \\ ${ }^{4}$ United States Department of Agriculture-Agricultural Research Service, Soil Dynamics Research, Auburn, Al, \\ USA \\ ${ }^{5}$ Department of Biosystems Engineering, Auburn University, Auburn, AL, USA \\ Correspondence: Jose Franco Da Cunha Leme Filho, School of Plant \& Environmental Sciences, Virginia \\ Polytechnic Institute \& State University, 330 Smyth Hall, 185 Ag Quad Lane, Blacksburg, VA 24061, USA. \\ E-mail: jfleme@vt.edu; jfleme2@gmail.com
}

Received: June 25, 2020

doi:10.5539/jas.v12n9p34
Accepted: August 2, $2020 \quad$ Online Published: August 15, 2020

URL: https://doi.org/10.5539/jas.v12n9p34

\begin{abstract}
Agriculture is the largest consumer of water in the United States. Results from previous studies have shown that it is possible to substantially reduce irrigation amounts and maintain corn yield. The objectives of this study were to evaluate the advantages and disadvantages of two irrigation scheduling methods for corn production in Alabama. Two irrigation scheduling methods evaluated were: a) Checkbook, which is one of the conventional methods used by farmers that is based on the soil water balance estimated using water lost by evapotranspiration and its replacement through rainfall or irrigation, and b) Sensor-based, which was based on soil matric potential values recorded by soil moisture tension sensors installed in the field. The experimental field was divided into two irrigation management zones (zone A and zone B) based on soil properties of each field. During the 2014 season in zone A, significant grain yield differences were observed between the two irrigation methods. The Checkbook plots exhibited greater yield than Sensor-based plots: $10181 \mathrm{~kg} \mathrm{ha}^{-1}$ and $9696 \mathrm{~kg} \mathrm{ha}^{-1}$, respectively. The greater yield on the Checkbook plots could be associated with higher irrigation rate applied, $148 \mathrm{~mm}$ more, compared with the Sensor-based plots. In zone B, there were no significant yield differences between both irrigation methods; however, Sensor-based plots out yielded Checkbook plots, with $9673 \mathrm{~kg} \mathrm{ha}^{-1}$ and $9584 \mathrm{~kg}$ $\mathrm{ha}^{-1}$, respectively. Even though the irrigation amount applied in Checkbook located in zone B was higher, 102 $\mathrm{mm}$ more, there were no significant yield differences. Therefore, it suggests that the Sensor-based method was promissory irrigation scheduling strategy under the conditions of zone B. In 2015, there were no significant grain yield differences between zone A and zone B when the data from the Checkbook plots were analyzed. However, the Sensor-based treatment produced a statistically significant difference of grain yield of $13597 \mathrm{~kg} \mathrm{ha}^{-1}$ in zone $\mathrm{A}$ and $11659 \mathrm{~kg} \mathrm{ha}^{-1}$ in zone B, also both zones received the same amount of irrigation. Overall results of both growing seasons indicated that the use of the Sensor-based irrigation scheduling treatment resulted in similar values of total profit per hectare when compared to Checkbook method. The Sensor-based method seems a promising strategy that could result in water and financial savings, but more research is required.
\end{abstract}

Keywords: variable rate irrigation, VRI, maize, precision agriculture, soil moisture sensor

\section{Introduction}

Increases in water demand to support population and economic growth, environmental flows, and the energy-sector have resulted in water shortages for many regions of the world. The lack of appropriate water management practices and integrated water use policies will increase water-related problems in terms of population demand and environmental impacts. Production of agricultural crops could be severely impacted by current and future water shortages. In this scenario, the agricultural sector plays a critical role in terms of water 
consumption. Worldwide, irrigated agriculture accounts for about 70 percent of total freshwater withdrawals (Molden et al., 2007). In Alabama, even though irrigation adoption is low compared with other states, it should be accompanied with practices that allow farmers to use the water resource effectively and efficiently, while achieving high yields. Based on the 2012 Census of Agriculture, irrigated land in Alabama is small compared with neighboring state $-5.1 \%$ of harvested cropland in Alabama is irrigated compared to $30.8 \%$ in Georgia. However, the adoption of irrigation, mainly center pivot irrigation systems, has increased from 79,647 acres or 32,231 ha in 1997 to 113,008 acres or 45,732 ha in 2012 (NASS, 2016). An estimated 20 percent of the world's cultivated land is irrigated, accounting for 40 percent of total agricultural production (Rosegrant, Ringler, \& Zhu, 2009). Projections for food and agricultural production assume that the world's population will reach about 9.6 billion people by 2050 (United Nations, 2001), thus higher yields obtained under irrigation systems are helping to feed the growing population. Furthermore, observations of recent growth rates in yields of major crops indicated the need for research incentive and financial investments, in order to continue increasing yields. Currently, the agricultural productivity concern is because the yields increment may not be rising in the same proportion to meet world demands (Ray, Mueller, West, \& Foley, 2013).

Irrigation is enabling producers to achieve higher yields and at the same time making agriculture feasible in areas with low precipitation. However, the agricultural sector is facing the challenge of creating mechanisms to increase the crop production with less water, consequently increasing crop water productivity (Zwart \& Bastiaanssen, 2004). Several possible approaches such as efficient irrigation scheduling methods and improved irrigation technologies may be adopted for more conscious use of limited water resources (Kirda, 2002). Even though several smart-irrigation technologies are available to assist growers in estimating the right rate and the right time to deliver site-specific irrigation rates (Keswani et al., 2019; Munir, Bajwa, Naeem, \& Ramzan, 2018), adoption is still low. As of 2013, the most recent Farm and Ranch Irrigation Survey indicated that $72 \%$ of irrigated U.S. farms still rely either on a fixed schedule or on visual cues of plant stress, such as wilting to schedule irrigation. Among the science-based irrigation scheduling tools adopted, only $10 \%$ use soil moisture sensors, $8 \%$ use reports on daily crop-water evapotranspiration (ET), and $8 \%$ use web-based irrigation scheduling services (NASS, 2016). In Alabama, of the 1022 farms using any method for deciding when to irrigate, $7 \%$ use soil moisture sensors and $4 \%$ use reports on daily crop-water ET (NASS, 2016).

Furthermore, Variable rate irrigation (VRI) is included as one of the irrigation technology innovations that can make irrigation scheduling feasible and more precise in terms of water application according to within-field variability. Variable rate irrigation is recommended to apply the appropriate amount of water in the right time considering field-level spatiotemporal heterogeneity (Duncan, 2012). Variable rate irrigation is expected to decrease nutrient leaching, but also increase water-use efficiency, productivity, and fuel savings (Pan, Adamchuk, Martin, Schroeder, \& Ferguson, 2013). As with irrigation scheduling tools, adoption of VRI has also been slow in 2008, of the 175,000 center pivot and linear move sprinkler systems in the U.S., less than 200 had VRI capabilities (NASS, 2007). Therefore, it is important to test and measure advantages and limitations of these technologies to guide producers and increase the implementation of more efficient practices. Variable rate irrigation has obvious potential advances to conserve water use by turning off sprinklers over non-planted areas, farm tracks, drains, etc., as well as varying the timing and amount of irrigation according to different crop and soil types. Several authors have reported on the potential for water conservation that has been observed using VRI systems (Evans, Han, \& Kroeger, 1996; Hedley \& Yule, 2009; Sadler, Evans, Stone, \& Camp, 2005).

Mutual use of VRI and irrigation scheduling as water management strategies can prevent over-application of water and minimize yield losses due to water shortage or drought stress. In general, methods of irrigation scheduling can be classified as plant, soil, climate-based, or combinations. The Checkbook method, the simplest way to conduct irrigation scheduling, gives irrigation directions for crop management according to the soil water deficit calculated from soil water balance data and it can be a good water management tool when used properly (Broner, 1989; Lundstrom \& Stegman, 1988; Wright \& Bergsrud, 1991). Jones (2004) stated that this method successfully worked for several conditions, however, if the producer does not carefully record water balance data, errors may add up over time. On the other hand, various types of sensing devices have been created and made commercially available to assist the producer with irrigation management. Some of these devices are capable of wirelessly transferring data collected from their sensors. Several types of soil moisture sensors have been evaluated by researchers in terms of accuracy, reliability, and cost (Chanzy et al., 1998; Evett \& Parkin, 2005; Kizito et al., 2008; Seyfried \& Murdock, 2004; Yao, Wierenga, Graham, \& Neuman, 2004). Vellidis, Tucker, Perry, Kvien, and Bednarz (2008) developed and evaluated a wireless smart sensor array as a tool to conduct irrigation scheduling. This wireless sensor system can continuously measure soil water tension and soil and air temperature, which offer competitive advantages as a potential irrigation scheduling tool. In the study, the same 
soil moisture sensor developed by Vellidis, Tucker, Perry, Kvien, and Bednarz (2008) was compared against the Checkbook irrigation scheduling method. Therefore, the objectives of this study were to evaluate, under on-farm conditions, yield and water use differences between these two irrigation scheduling methods for corn production in Alabama.

\section{Materials and Methods}

\subsection{Site Description}

The study was conducted at the E. V. Smith Research Center (EVSREC) in Shorter, AL $\left(32^{\circ} 25^{\prime} 43.43^{\prime \prime} \mathrm{N}\right.$, $85^{\circ} 53^{\prime} 34.81^{\prime \prime} \mathrm{W}, 69 \mathrm{~m}$ above mean sea level). In 2014, the site was a 2.4 ha field located at EVS—Plant breeding unit and the dominant soil series was Kalmia loamy sand (Fine-loamy, mixed, semiactive, thermic Aquic Hapludults) with $0 \%$ to $3 \%$ slope. In 2015, the site was a 6 ha field at EVS-Farm Services unit and the dominant soil series were Altavista silt loam (Fine-loamy over sandy or sandy-skeletal, siliceous, semiactive, thermic Typic Hapludults) and Cahaba sandy loam (Fine-loamy, siliceous, semiactive, thermic Typic Hapludults) with $0 \%$ to $2 \%$ slope (USDA, 2011). In general, rainfall during both growing seasons (April-August) was above the historic 20-year average (1971-2000).

Corn was planted in mid-April, and cultural practices were performed according to Alabama Cooperative Extension Service recommendations. Each corn field was planted with $0.90 \mathrm{~m}$ row spacing and seeding rate of 88,956 seeds ha ${ }^{-1}$. The crop was fertilized with $280 \mathrm{~kg} \mathrm{~N} \mathrm{ha}^{-1}$ as urea ammonium-nitrate (UAN 28-0-0); one third of the total $\mathrm{N}$ was applied at planting and the remaining at the $\mathrm{V} 6$ growth stage.

\subsection{Experimental Design}

The study in both years was arranged into two management zones delineated according to soil textural properties. The distinct zones were defined based on soil texture analysis conducted in both growing seasons and a soil electrical conductivity survey. In 2014, zones A and B were characterized by using the average soil texture data collected from three samples on each zone. Thus, in 2014 and 2015, the zone A and B were described according to characteristics of textural class and percent of sand, silt and clay.

Two irrigation scheduling strategies were evaluated within each zone: a) Checkbook Irrigation Scheduling Method and b) Sensor-based Irrigation Scheduling Method. A six-row John Deere 9470 grain combine with a yield monitor was used to harvest the test. The system used an AgGPS 132 DGPS receiver with differential correction to calculate the position of the grain combine during harvest.

\subsection{Soil Electric Conductivity Mapping}

According to Corwin and Lesch (2003), soil ECa is a function of several soil properties that include soil salinity, soil texture, and water content. The capacity of soil to retain water against gravity depends on soil texture among other characteristics (Aina \& Periaswamy, 1985). Therefore, an indirect assessment of within-field soil texture variability allowed the identification of zones with differences in soil water holding capacity, under which irrigation scheduling practices were tested. The Veris 3100 Sensor Cart (Veris Technologies., Salina, KS, USA) was used to map soil electrical conductivity (ECa). The sensor uses disks with electrodes that once are in physical contact with the soil, send an electrical current into the soil and measure the drop in voltage. The soil ECa mapping system uses a sensor cart with a GPS antenna which while pulled through the field with a small tractor, records georeferenced soil ECa values. The sensor collects soil ECa at two soil depths: $0-30 \mathrm{~cm}$ (shallow, ECa-s) and 0-90 cm (deep, ECa-d). The correlation of soil ECa with soil properties stems from the fact that sandy soil textures have a low conductivity, silts have a medium conductivity and clays have a high conductivity. Consequently, conductivity measured at low frequencies correlates strongly to soil particle size and texture (Williams \& Hoey, 1987). The spatial soil ECa data collected from each field was imported into a GIS in order to create soil ECa map. Based on the within field soil ECa variability, zones with similar values of soil ECa were identified using the Management Zone Analyst software (MZA 1.0.1, USDA-ARS, Columbia, Mo., USA). The MZA utilizes the fuzzy $c$-means algorithm and the Euclidean or Mahalanobis distances to separate data into clusters with similar attributes (Fridgen et al., 2004). Evans, LaRue, Stone, and King (2013) stated the importance and critical need to dynamically develop irrigation management zones (MZ) in an accurate and inexpensive manner. After the data was processed through MZA, two management zones were identified and delineated for each field.

Zones were delineated based on soil ECa data with information about how the ECa data collection was conducted is provided in a subsequent section. Corn was then planted, and soil moisture sensor probes were installed in each zone. After the probes were placed in $60 \mathrm{~cm}$ holes, a slurry was added in the holes to fill up and 
promote good contact between soil moisture probes and the ground. Antennas and electronic boards were properly configured, and the base station was set in the border of the experimental field.

\subsection{Soil Water Retention Curve Generation}

Disturbed soil samples were collected at three soil depths $(15,30$ and $60 \mathrm{~cm})$ at the same locations where soil sensor probes were installed in each zone (A and B) at the beginning of each season. The soil samples were used for a soil textural analysis, which provided information to describe and verify results obtained from the soil ECa survey. Also, the percentage of sand, silt and clay obtained from this analysis was used to generate a Soil Water Retention Curves (SWRC) for three soil depths using the Retention Curve (RECT) Computer Program (U.S. Salinity Laboratory, USDA, ARS, Riverside, California).

Soil texture analysis provided the percent of sand, silt and clay values and these data were input in the RETC Computer Program, which calculates the van Genuchten equation parameters: $\theta_{\mathrm{r}}, \theta_{\mathrm{s}}$, $\alpha$, and $\mathrm{n}$ (Tables 1 and 2). The van Genuchten equation is often used to describe the SWRC function in unsaturated soil. The van Genuchten model has the following form:

$$
\theta_{\mathrm{h}}=\theta_{\mathrm{r}}+\frac{\theta_{\mathrm{S}}-\theta_{\mathrm{r}}}{\left[1+(\alpha \mathrm{h})^{\mathrm{n}}\right)^{\mathrm{m}}}
$$

where, $\theta_{\mathrm{h}}$ is the actual soil water content $\left(\mathrm{cm}^{3} \mathrm{~cm}^{-3}\right)$ at the suction $\mathrm{h}(\mathrm{cm}$, taken positive for increasing suctions); $\theta_{\mathrm{r}}$ and $\theta_{\mathrm{s}}$ are residual and saturated soil water contents $\left(\mathrm{cm}^{3} \mathrm{~cm}^{-3}\right)$, respectively; $\alpha$ is a parameter related to the inverse of the air entry suction $\left(\mathrm{cm}^{-1}\right)$; $\mathrm{m}$ and $\mathrm{n}$ are curve shape parameters (Van Genuchten, 1980). The " $\mathrm{m}$ " parameter on this equation characterizes the asymmetry and it can be calculated as $\mathrm{m}=1-1 / \mathrm{n}$.

Table 1. van Genuchten equation parameters and soil texture properties for three soil depths of the management zones delineated in 2014 at the EVSREC

\begin{tabular}{|c|c|c|c|c|c|c|}
\hline Depth (cm) & \multicolumn{2}{|c|}{$0-15$} & \multicolumn{2}{|c|}{$15-30$} & \multicolumn{2}{|c|}{$30-60$} \\
\hline Zone & Zone A & Zone B & Zone A & Zone B & Zone A & Zone B \\
\hline$\theta \mathrm{r} \neq$ & 0.0422 & 0.0555 & 0.04 & 0.0644 & 0.0515 & 0.0823 \\
\hline$\theta \mathrm{s} \S$ & 0.3837 & 0.3944 & 0.3857 & 0.4011 & 0.3788 & 0.4424 \\
\hline$\alpha \rrbracket$ & 0.0382 & 0.0149 & 0.0373 & 0.0162 & 0.0325 & 0.0112 \\
\hline$n £$ & 1.5215 & 1.4404 & 1.4526 & 1.4122 & 1.429 & 1.4286 \\
\hline$m a$ & 0.3428 & 0.3057 & 0.3116 & 0.2919 & 0.3002 & 0.3000 \\
\hline$\theta \mathrm{s}-\theta \mathrm{r} ¥$ & 0.3415 & 0.3389 & 0.3457 & 0.3367 & 0.3273 & 0.3601 \\
\hline$\%$ Sand & 75.83 & 49.17 & 71.67 & 47.5 & 73.33 & 29.17 \\
\hline$\%$ Silt & 15.83 & 34.16 & 20 & 30.83 & 12.5 & 38.33 \\
\hline$\%$ Clay & 8.34 & 16.67 & 8.33 & 21.67 & 14.17 & 32.5 \\
\hline Textural Class & Sand Loam & Loam & Sand Loam & Loam & Sand Loam & Clay Loam \\
\hline
\end{tabular}

Note. ‡ Residual soil water content $\left(\mathrm{cm}^{3} \mathrm{~cm}^{-3}\right) ; \S$ Saturated soil water content $\left(\mathrm{cm}^{3} \mathrm{~cm}^{-3}\right)$; ๆ Parameter related to the inverse of the air entry suction $\left(\mathrm{cm}^{-1}\right) ; £ \mathrm{n}$ curve shape parameter (empirical parameters); $\propto \mathrm{m}=(1-1 / \mathrm{n}) ; ¥ \theta \mathrm{r}$ and $\theta \mathrm{s}$ are the residual and saturated soil water contents $\left(\mathrm{cm}^{3} \mathrm{~cm}^{-3}\right)$.

Table 2. van Genuchten equation parameters and soil texture properties for three soil depths of the management zones delineated in 2015 at EVSREC

\begin{tabular}{|c|c|c|c|c|c|c|}
\hline \multirow{2}{*}{$\begin{array}{l}\text { Depth }(\mathrm{cm}) \\
\text { Zone }\end{array}$} & \multicolumn{2}{|c|}{$0-15$} & \multicolumn{2}{|c|}{$15-30$} & \multicolumn{2}{|c|}{$30-60$} \\
\hline & Zone A & Zone B & Zone A & Zone B & Zone A & Zone B \\
\hline$\theta \mathrm{r} \neq$ & 0.0652 & 0.0972 & 0.0887 & 0.1036 & 0.0891 & 0.0967 \\
\hline$\theta \mathrm{s} \S$ & 0.3829 & 0.4887 & 0.4493 & 0.513 & 0.4423 & 0.4837 \\
\hline$\alpha \boldsymbol{q}$ & 0.0274 & 0.012 & 0.0182 & 0.0179 & 0.023 & 0.0199 \\
\hline$n £$ & 1.3149 & 1.3904 & 1.29 & 1.2394 & 1.244 & 1.225 \\
\hline$m \alpha$ & 0.2395 & 0.2808 & 0.2248 & 0.1932 & 0.1961 & 0.1837 \\
\hline$\theta \mathrm{s}-\theta \mathrm{r} ¥$ & 0.3177 & 0.3915 & 0.3606 & 0.4094 & 0.3532 & 0.387 \\
\hline$\%$ Sand & 62.5 & 11.89 & 30.63 & 6.88 & 35 & 20 \\
\hline$\%$ Silt & 13.13 & 45.68 & 26.25 & 31.25 & 19.38 & 23.13 \\
\hline$\%$ Clay & 24.38 & 42.43 & 43.12 & 61.87 & 45.62 & 56.87 \\
\hline Textural Class & Sand Clay Loam & Silty Clay & Clay & Clay & Clay & Clay \\
\hline
\end{tabular}

Note. ‡ Residual soil water content $\left(\mathrm{cm}^{3} \mathrm{~cm}^{-3}\right) ; \S$ Saturated soil water content $\left(\mathrm{cm}^{3} \mathrm{~cm}^{-3}\right)$; ๆ Parameter related to the inverse of the air entry suction $\left(\mathrm{cm}^{-1}\right) ; £ \mathrm{n}$ curve shape parameter (empirical parameters); $\propto \mathrm{m}=(1-1 / \mathrm{n}) ; ¥ \theta \mathrm{r}$ and $\theta \mathrm{s}$ are the residual and saturated soil water contents $\left(\mathrm{cm}^{3} \mathrm{~cm}^{-3}\right)$. 
The solution of this equation provided enough data to generate the SWRC for three soil depths and allows the estimation of the soil water content at different soil matric potential levels (Figures 1, 2, 3 and 4).
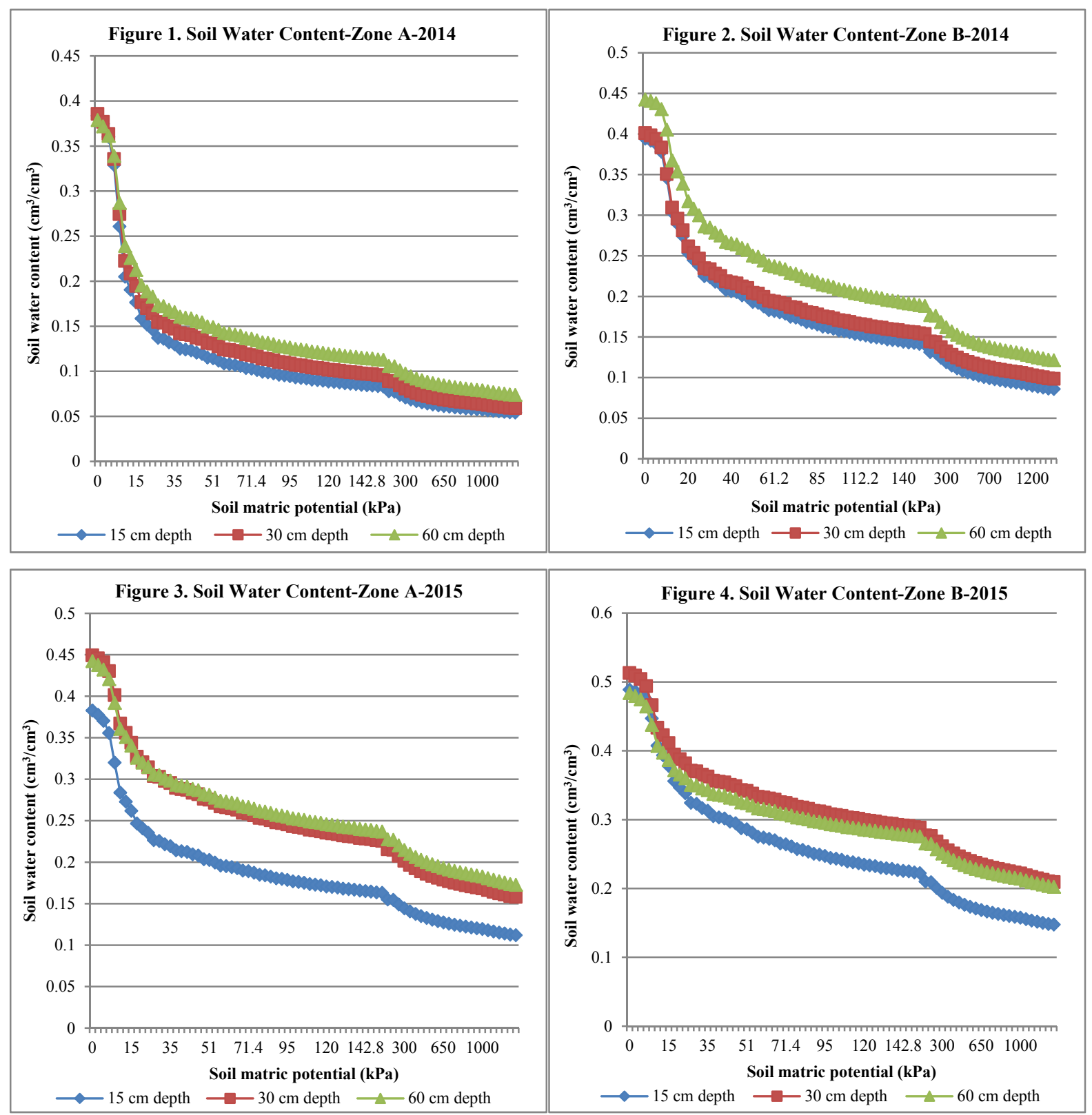

Figures 1, 2, 3, \& 4. Soil water retention curves of the zone A and B created using the van Genuchten equation for each depth $(15,30$ and $60 \mathrm{~cm})$ to convert soil water content data in soil matric potential in 2014 and 2015 at EVSREC

\subsection{Plant Available Water and Manageable Allowed Depletion (Irrigation Threshold)}

Once the SWRCs were generated, the field capacity and permanent wilting point values at soil depths of 15, 30, and $60 \mathrm{~cm}$ for each field were identified. These parameters are key for estimation of Plant available water (PAW). Studies have found that field capacity does not correspond to a fixed soil matric potential value; in contrast, it changes with soil texture. Richards and Weaver (1944) found that a coarse-textured soil can reach field capacity at $10 \mathrm{kPa}$ and a fine-textured soil can reach field capacity at $33 \mathrm{kPa}$. The permanent wilting point is usually found at a soil matric potential of $1500 \mathrm{kPa}$. Therefore, for the purposes of this study soil matric potential values representing field capacity were selected based on soil texture determined for each management zone. 
The field capacity and permanent wilting point were established, and the PAW was calculated using field capacity minus permanent wilting point (Tables 3 and 4). After PAW was calculated, the irrigation threshold was determined. The Manageable Water Depletion (MAD) is described as how much water to reduce from PAW before initiating an irrigation event. In this study, the irrigation threshold or MAD was set based on $35 \%$ depletion of PAW (Tables 3 and 4). Irmak et al. (2012) also used 35\% depletion of PAW in a study testing irrigation strategies based on soil moisture sensors. The $35 \%$ to $38 \%$ depletion of PAW was used to conduct an agricultural water management demonstration network and the threshold point was lower than the traditional strategy of irrigation at 50\% depletion of PAW because it accounted for the time it takes a center pivot system to make one full circle (Irmak et al., 2010).

Table 3. Soil hydraulic properties-Field Capacity, Permanent Wilting Point, Plant Available Water-and soil moisture and matric potential at 35\% soil water depletion for three soil depths of the management zones delineated in 2014 at EVSREC

\begin{tabular}{|c|c|c|c|c|c|c|}
\hline \multirow{2}{*}{$\begin{array}{l}\text { Depth }(\mathrm{cm}) \\
\text { Zone }\end{array}$} & \multicolumn{2}{|c|}{$0-15$} & \multicolumn{2}{|c|}{$15-30$} & \multicolumn{2}{|c|}{$30-60$} \\
\hline & $\mathrm{A}$ & $\mathrm{B}$ & A & $\mathrm{B}$ & $\mathrm{A}$ & $\mathrm{B}$ \\
\hline Field Capacity $(\mathrm{FC}) \neq$ & 0.2049 & 0.218 & 0.2225 & 0.2281 & 0.239 & 0.2785 \\
\hline Permanent Wilting Point (PWP) $\S$ & 0.0545 & 0.087 & 0.0595 & 0.099 & 0.0743 & 0.1219 \\
\hline Plant Available Water (PAW) 9 & 0.1504 & 0.132 & 0.163 & 0.1291 & 0.1647 & 0.1566 \\
\hline Water Depletion $(35 \%)\left(\mathrm{cm}^{3} \mathrm{~cm}^{3}\right) £$ & 0.0526 & 0.046 & 0.057 & 0.0451 & 0.0576 & 0.0548 \\
\hline $35 \%$ of PAW $\left(\mathrm{cm}^{3} \mathrm{~cm}^{3}\right) \alpha$ & 0.1523 & 0.1719 & 0.1654 & 0.1829 & 0.1813 & 0.2236 \\
\hline $35 \%$ of PAW $(\mathrm{kPa}) ¥$ & 20 & 74 & 24 & 78 & 25 & 78 \\
\hline
\end{tabular}

Note. $\ddagger\left(\mathrm{cm}^{3} \mathrm{~cm}^{3}\right) ; \S\left(\mathrm{cm}^{3} \mathrm{~cm}^{3}\right) ;$ - PAW = FC - PWP; $£$ Water Depletion $(35 \%)=$ PAW $\times 0.35-35 \%$ was the soil water depletion selected in the study; $035 \%$ of PAW $\left(\mathrm{cm}^{3} \mathrm{~cm}^{3}\right)=$ PAW - Water Depletion $(35 \%)$; $¥ 35 \%$ of PAW $(\mathrm{kPa})=$ soil matric potential referred to the depletion of $35 \%$ of PAW.

Table 4. Soil hydraulic properties-Field Capacity, Permanent Wilting Point, Plant Available Water-and soil moisture and matric potential at 35\% soil water depletion for three soil depths of the management zones delineated in 2015 at EVSREC

\begin{tabular}{|c|c|c|c|c|c|c|}
\hline \multirow{2}{*}{$\begin{array}{l}\text { Depth }(\mathrm{cm}) \\
\text { Zone }\end{array}$} & \multicolumn{2}{|c|}{$0-15$} & \multicolumn{2}{|c|}{$15-30$} & \multicolumn{2}{|c|}{$30-60$} \\
\hline & $\mathrm{A}$ & $\mathrm{B}$ & $\mathrm{A}$ & $\mathrm{B}$ & $\mathrm{A}$ & $\mathrm{B}$ \\
\hline Field Capacity $(\mathrm{FC}) \neq$ & 0.2838 & 0.3129 & 0.367 & 0.3564 & 0.361 & 0.3427 \\
\hline Permanent Wilting Point (PWP) $\S$ & 0.1126 & 0.1483 & 0.1591 & 0.2103 & 0.174 & 0.2035 \\
\hline Plant Available Water (PAW) 9 & 0.1712 & 0.1646 & 0.2079 & 0.1461 & 0.187 & 0.1392 \\
\hline Water Depletion $(35 \%)\left(\mathrm{cm}^{3} / \mathrm{cm}^{3}\right) £$ & 0.0599 & 0.0576 & 0.0727 & 0.0511 & 0.065 & 0.0487 \\
\hline $35 \%$ of PAW $\left(\mathrm{cm}^{3} / \mathrm{cm}^{3}\right) \propto$ & 0.2239 & 0.2553 & 0.2942 & 0.3052 & 0.2951 & 0.2939 \\
\hline $35 \%$ of PAW $(\mathrm{kPa}) ¥$ & 30 & 80 & 31 & 100 & 35 & 99 \\
\hline
\end{tabular}

Note. $\ddagger\left(\mathrm{cm}^{3} \mathrm{~cm}^{3}\right) ; \S\left(\mathrm{cm}^{3} \mathrm{~cm}^{3}\right) ;$ - PAW = FC - PWP; $£$ Water Depletion $(35 \%)=$ PAW $\times 0.35-35 \%$ was the soil water depletion selected in the study; $0.35 \%$ of PAW $\left(\mathrm{cm}^{3} \mathrm{~cm}^{3}\right)=$ PAW - Water Depletion (35\%); $¥ 35 \%$ of PAW $(\mathrm{kPa})=$ soil matric potential referred to the depletion of $35 \%$ of PAW.

The matric potential value $(\mathrm{kPa})$ associated with water content retained in the soil was important because soil moisture sensors provide data in matric potential units $(\mathrm{kPa})$. The most useful soil matric potential values correspond to $35 \%$ depletion of PAW, because these values indicate the threshold to start irrigation events using the Sensor-based irrigation scheduling method. The soil matric potential values that corresponded to the $35 \%$ depletion from PAW at various soil sensing locations within each zone were established (Tables 3 and 4). An average soil matric potential value per zone was determined for each field-season.

During both growing seasons, there were some differences in how soil matric potential threshold was stablished to indicate the necessity of irrigation. In 2014 and 2015, for growth stages before flowering, the soil matric potential representing the $35 \%$ depletion of PAW (irrigation threshold) corresponded to the average of soil matric potential values at the $0-15 \mathrm{~cm}$ and $15-30 \mathrm{~cm}$ soil depth. After flowering, the average of soil matric potential corresponded to the average of the three soil depths $(0-15,15-30$, and 30-60 cm). This procedure was conducted separately for data values that corresponded to Zone A and Zone B. Thus, the irrigation threshold in 2014 was 23 $\mathrm{kPa}$ and $76 \mathrm{kPa}$ for the zones A and B, respectively (Table 3). In 2015, the soil matric potential values 
representing the irrigation threshold were $32 \mathrm{kPa}$ and $93 \mathrm{kPa}$ for the zones A and $\mathrm{B}$, respectively (Table 4). The irrigation threshold values were indirectly influenced by field capacity values that in some cases were selected based on a matric potential at $10 \mathrm{kPa}$ and in other cases at $33 \mathrm{kPa}$ according to the soil texture in the area (Richards \& Weaver, 1944). Even though protocols established for this study selected the value of matric potential of $10 \mathrm{kPa}$ to determine field capacity in areas characterized by higher percent sand content than clay, the soil texture of our soils was neither sandy nor clay but something in between (Tables 1 and 2). Therefore, we decided to be more conservative and the irrigation thresholds values were slightly modified, increased, or decreased, depending on the situation and observations of soil differences during field visits and soil sampling campaigns. As a result of these analyses, in 2014 the final irrigation threshold values were set to $25 \mathrm{kPa}$ and $60 \mathrm{kPa}$ for zones $\mathrm{A}$ and $\mathrm{B}$, respectively to reflect soil characteristics that were neither sand nor clay. A similar process was followed with the 2015 data; the final irrigation threshold values were set to $55 \mathrm{kPa}$ and $80 \mathrm{kPa}$ for zones A and B, respectively.

\subsection{Irrigation Scheduling Strategies}

Both irrigation scheduling methods tested in this study differed from each other in the way the amount of water stored in the soil during the growing season is calculated. The Checkbook Irrigation Scheduling Method was based on managing the estimated crop's evapotranspiration (ET) using meteorological parameters and replacing the consumptive water use. On the other hand, the Sensor-based irrigation method relied on values of soil water tension sensors to determine irrigation times.

\subsubsection{Checkbook Irrigation Scheduling Method}

The Checkbook method was evaluated daily accounting for crop water demand and water input from rainfall and irrigation. Therefore, parameters such as growth of the crop, maximum air temperature of each day, daily ET estimation from the crop water use, rainfall, and/or irrigation applied to the field were monitored. Rainfall and maximum temperature were frequently checked from E. V. Smith weather stations linked to the AWIS Weather Service (www.awis.com). Every irrigation event, amount and date were recorded and used in the calculations. Weekly plant water demand was determined using University of Georgia Extension recommendations for Corn (Lee et al., 2014). The soil water deficit balance was calculated by considering the amount of water added and removed from the soil. Each day, the estimated crop water use was added to the previous day's soil water deficit, and any rainfall or irrigation amounts were subtracted from this deficit. The daily water demand balance was summarized every week and irrigation (if necessary) was applied. If a weekly balance of rainfall or irrigation minus weekly crop water use was greater than the current deficit, most of the excess was considered lost due to deep percolation below the rooting zone, and the new deficit balance was generally set to zero.

\subsubsection{Sensor-Based Irrigation Scheduling Method}

Irrigation events from the Sensor-based irrigation scheduling method were determined using information from sensors probes properly installed between two corn plants in the experimental area. The sensors probes recording soil water tension data were part of a smart sensor array system. The smart sensor array system used in this study consisted of a centrally located receiver connected to a laptop computer (base station) with multiple sensor nodes installed in the field. The sensor nodes consisted of sensors ( 3 soil moisture sensors (Watermark $\mathbb{R}$ ) and thermocouples, a sensor circuit board, and an active transmitter, which transmitted data to the receiver (Vellidis, Tucker, Perry, Kvien, \& Bednarz, 2008). The smart sensor board acquired sensor values and wirelessly transmitted those values to a centrally located radio frequency receiver (base station), and then via cellphone signal, the data was sent to a website. The board of each node was able to read up to three Watermark ${ }^{\circledR}$ soil water tension sensors located at three different soil depths $(15,30$ and $60 \mathrm{~cm})$ enabling a better view of the water availability in the root zone. Each Watermark ${ }^{\circledR}$ sensor is a granular matrix device used to measure soil water tension, therefore all data obtained from the Watermarks sensors was transferred to the database in kilopascal $(\mathrm{kPa})$ units. Watermark ${ }^{\circledR}$ sensors provided continuous data analogous to the force (soil matric potential) that corn roots must exert to extract water from the soil and these values were used to schedule irrigation. Watermark ( $)$ sensors have been used to measure soil water status for irrigation management and other purposes for more than two decades (Armstrong, Ligon, \& Thomson, 1985; Bausch \& Bernard, 1996; Mitchell \& Shock, 1996; Thomson, Younos, \& Wood, 1996).

Soil moisture sensors provide soil matric potential values for the irrigation threshold using (kPa) units. As mentioned above, the irrigation threshold was $23 \mathrm{kPa}$ for zone A and $62 \mathrm{kPa}$ for zone B in the 2014 growing season. In 2015, the irrigation threshold was $55 \mathrm{kPa}$ and $80 \mathrm{kPa}$ for zone A and B, respectively. Thus, an irrigation event was initiated when soil matric potential reached the irrigation threshold. Weather conditions were also considered before initiating irrigation. For instance, if the irrigation threshold was reached, but the weather 
forecast indicated a high probability of rain for the following days, irrigation was postponed, or the irrigation amount was decreased. However, when no chance or low chance of rain was predicted, irrigation was applied to bring the soils to field capacity. When the corn reached the black layer (physiological maturity), irrigation was discontinued, and the soil probes were removed before harvest time.

\subsubsection{Variable Rate Irrigation}

The irrigation system at the experimental site (EVS) included variable rate irrigation technology. The variable rate irrigation was essential because soil texture zones reached the irrigation threshold at different times during the growing season and water was applied independently for each zone. For instance, if zone A reached the irrigation threshold but the tension values in zone B were not close to the threshold, the irrigation pivot was initiated, and sprinklers were applying water only over zone A. Therefore, the variable rate irrigation was required to split irrigation amounts over the plots. Also, this technology minimized water waste because of the capability to turn off the sprinklers when the pivot is crossed the gravel road or non-planted areas.

\subsection{Water Productivity and Economic Analysis}

Average water productivity is estimated by dividing crop yield by total applied water (rainfall plus irrigation) (Molden, 1997). Water productivity was analysed by growing season to evaluate grain yield and water use between irrigation scheduling methods within each management zone. The relationship between crop production and water received is a crop water production function. According to Vaux Jr and Pruitt (1983), this function can be categorized into three groups depending on a desirable level of water use: (1) agronomists and other production-oriented scientists trying to identify the level of water input necessary to achieve maximum yield per unit land, (2) irrigation engineers trying to maximise water use efficiency, and (3) economists trying to establish the water level that is equivalent to the revenue obtained as a result of its application.

The economic analysis was conducted using total income per hectare referred as the total grain yield per hectare multiplied by the current price of corn grain. The corn grain price fluctuated around $\$ 3.60$ per bushel during the second half of June 2015 . The $\$ 3.60$ per bushel was referred as $\$ 3.60$ per $25.4 \mathrm{~kg}$ of corn grain or $\$ 0.14 \mathrm{per} \mathrm{kg}$ of corn grain. Furthermore, the total income did not consider other crop management spending (i.e., seed price, mineral fertilizers, pest control and harvesting) because the objective of this study was to compare irrigation performance.

Irrigation cost methodology was based on a 24 ha Pivot Cost Analysis conducted by the Department of Biosystems Engineering of Auburn University (Dougherty et al., 2008). The initial cost of the irrigation system was not considered in this study because this cost can be depreciated through years and growing seasons. Therefore, only the annual cost of the irrigation system was considered to reflect the irrigation investment for one growing season. The annual ownership cost and the annual operating cost per acre-inch of water applied were equivalent at $\$ 19.78$ per acre-inch. One acre-inch corresponds to $62.78 \mathrm{~mm}$ per hectare which was used to define the price of irrigation in $\mathrm{mm}$ per hectare. Total irrigation during the season was multiplied per $\$ 0.32$ per $\mathrm{mm}$-ha in order to define total cost of irrigation. Total profit per acre was calculated using the total income per ha minus the total cost of irrigation per ha. Furthermore, the cost of sensors was not included based on life cycle use of the sensor system longer than two years, similar to the center pivot which has an even longer design life. Thus, the cost of the sensors system can be depreciated through several growing seasons.

The economic calculation was addressed in this study to illustrate the impact to the producer. For instance, grain yield differences could be considered statistically significant; however sometimes these differences do not impact the producer, financially. Because in order to obtain higher yield, the cost of crop production also increases and sometimes the economical return do not worth the higher investment. Also, the economic returns eventually are not worth it when disadvantages such as environmental harm is considered.

\subsection{Statistical Analysis}

Spatial analysis of yield monitor data was conducted using ArcMap vr. 10.3.1 (ESRI). In 2014, a paired t-test was used to compare the effect of irrigation scheduling methods on grain yield within each soil-textural zone (PROC TTEST) implemented in SAS 9.1 (SAS for Windows v. 9.1, SAS Institute Inc., Cary, NC). As indicated by the two tales significance probability $(\mathrm{P}$ values $<0.0001)$ there is evidence that the variances for the two irrigation levels are unequal. Thus, the Satterthwaite method was used. In 2015, a split plot completely randomized design was implemented with soil-textural zones as main plot and irrigation scheduling methods as subplots and grain yield differences due to irrigation scheduling within and between zones were tested using generalized linear mixed models (PROC GLIMMIX) implemented in SAS 9.1 (SAS for Windows v. 9.1, SAS Institute Inc., Cary, NC). 


\section{Results and Discussion}

\subsection{Precipitation and Irrigation}

The 2014 growing season exhibited above normal rainfall (30-year average) in April (+104 mm) and May $(+17$ $\mathrm{mm})$, but below average in June $(-0.5 \mathrm{~mm})$, July $(-46 \mathrm{~mm})$ and August $(-17 \mathrm{~mm})$. In 2015, rainfall above the historic average (30 years average) was observed in April $(+18 \mathrm{~mm})$ and May $(+96 \mathrm{~mm})$ but below average in June $(-20 \mathrm{~mm})$, July $(-17 \mathrm{~mm})$, and August $(-11 \mathrm{~mm})$. The total rainfall during the growing season was above average in $2014(+56 \mathrm{~mm})$ and $2015(+66 \mathrm{~mm})$ (Table 5). The long-term average temperature (30 years average) of the entire growing season (April-August) was $23{ }^{\circ} \mathrm{C}$ and in average temperature in 2014 and 2015 was $22{ }^{\circ} \mathrm{C}$ and $23{ }^{\circ} \mathrm{C}$, respectively.

Table 5. Climatic conditions, including rainfall $(\mathrm{mm})$, average temperature $\left({ }^{\circ} \mathrm{C}\right)$, long-term $(30$ years) average values and irrigation amount $(\mathrm{mm})$ during the 2014 and 2015 growing seasons and measured at the research site in EVSREC. Data were collected at AWIS Weather Service (www.awis.com)

\begin{tabular}{|c|c|c|c|c|c|}
\hline Month & Rainfall (mm) & Temperature $\left({ }^{\circ} \mathrm{C}\right)$ & Checkbook (mm) & Sensor-Zone A $(\mathrm{mm})$ & Sensor-Zone B $(\mathrm{mm})$ \\
\hline \multicolumn{6}{|l|}{2014} \\
\hline March & 148 & 11.11 & $\mathrm{NI} \ddagger$ & NI & NI \\
\hline April & 223 & 16.67 & NI & NI & NI \\
\hline May & 113 & 20.56 & NI & NI & NI \\
\hline June & 112 & 24.44 & 30 & 15 & 30 \\
\hline July & 89 & 24.44 & 163 & 30 & 61 \\
\hline August & 75 & 24.44 & NI & NI & NI \\
\hline Total/Average & 612 & 22.11 & 193 & 45 & 91 \\
\hline \multicolumn{6}{|l|}{2015} \\
\hline March & 51 & 14.44 & NI & NI & NI \\
\hline April & 138 & 18.33 & NI & NI & NI \\
\hline May & 192 & 21.11 & 13 & 13 & 13 \\
\hline June & 93 & 25.00 & 57 & 38 & 38 \\
\hline July & 118 & 26.11 & 51 & 19 & 19 \\
\hline August & 82 & 25.56 & NI & NI & NI \\
\hline Total/Average & 622 & 23.22 & 121 & 70 & 70 \\
\hline \multicolumn{6}{|c|}{ Historic average (1971-2000) } \\
\hline March & 165 & 12.61 & NA $\S$ & NA & NA \\
\hline April & 120 & 16.22 & NA & NA & NA \\
\hline May & 96 & 20.50 & NA & NA & NA \\
\hline June & 113 & 24.44 & NA & NA & NA \\
\hline July & 135 & 26.28 & NA & NA & NA \\
\hline August & 93 & 25.89 & NA & NA & NA \\
\hline Total/Average & 556 & 22.67 & NA & NA & NA \\
\hline
\end{tabular}

Note. ₹ NI-No irrigation; § NA-Not applicable.

The study was conducted on different experimental fields in 2014 and 2015; however, the fields were located at the same research station and only less than $5 \mathrm{~km}$ from each other. The 2014 seasonal total rainfall (April-August) was $613 \mathrm{~mm}$ and $623 \mathrm{~mm}$ in 2015 (Table 5). Total rainfall was similar across years and above the historic average, which was $556 \mathrm{~mm}$. Total seasonal rainfall above the historic average could minimize the effect of irrigation on grain yield. However, rainfall distribution throughout the growing season has an impact on irrigation frequency and, consequently, on grain yield. Thus, if rainfall is concentrated during the period of high water demand, irrigation frequency and amount will decrease, but if rainfall is concentrated at the beginning or end of season; it does not have much impact on irrigation. Irmak et al. (2012) tested irrigation management strategies in large-scale farms with two growing seasons that had similar total rainfall, however the irrigation amount was lower in the second season because the rainfall distribution was different. Tasseling is the highest daily water demand for corn according to Corn Production Guide in Georgia (Lee et al., 2014). In 2014, corn plants received $22 \mathrm{~mm}$ and $25 \mathrm{~mm}$ of rain in the two weeks before and after tasseling, respectively. In 2015, rainfall amounts were $46 \mathrm{~mm}$ and $84 \mathrm{~mm}$ in the two weeks before and after tasseling, respectively. Although 
total rainfall was similar, rainfall distribution could influence the differences of irrigation amounts in both growing seasons.

\subsection{Seasonal Changes in Soil Matric Potential, Soil Water, and Irrigation Management}

Daily soil matric potential (SMP) changes at the 15,30 and $60 \mathrm{~cm}$ soil depth from the Sensor-based irrigation plots during the 2014 and 2015 seasons are presented in the Figures 5, 6, 7, and 8. In 2014 the sensor installed in zone A indicated that irrigation event was initiated when SPM values of at least one depth approached the threshold (23 kPa) (Figure 5). In zone B, the first irrigation event occurred when the irrigation threshold (62 $\mathrm{kPa})$ was reached, but even though water was applied through irrigation the SMP values continued increasing especially in the 15 and $30 \mathrm{~cm}$ soil depths. Subsequent irrigation events were not sufficient to decrease tension in the 15 and $30 \mathrm{~cm}$ depths, indicating that water uptake was very high in this period. The middle June and beginning of July is a period of high daily water demand (Silks emerging and Blister stage). Therefore, corn plants were using mainly the root zone between 0 to $30 \mathrm{~cm}$ to uptake water and irrigation applied was taken up very rapidly because soil water tension did not significantly decrease. However, after middle July, rainfall plus irrigation brought the tension down and no more irrigation was required because the SMP did not approach the threshold (Figure 6).

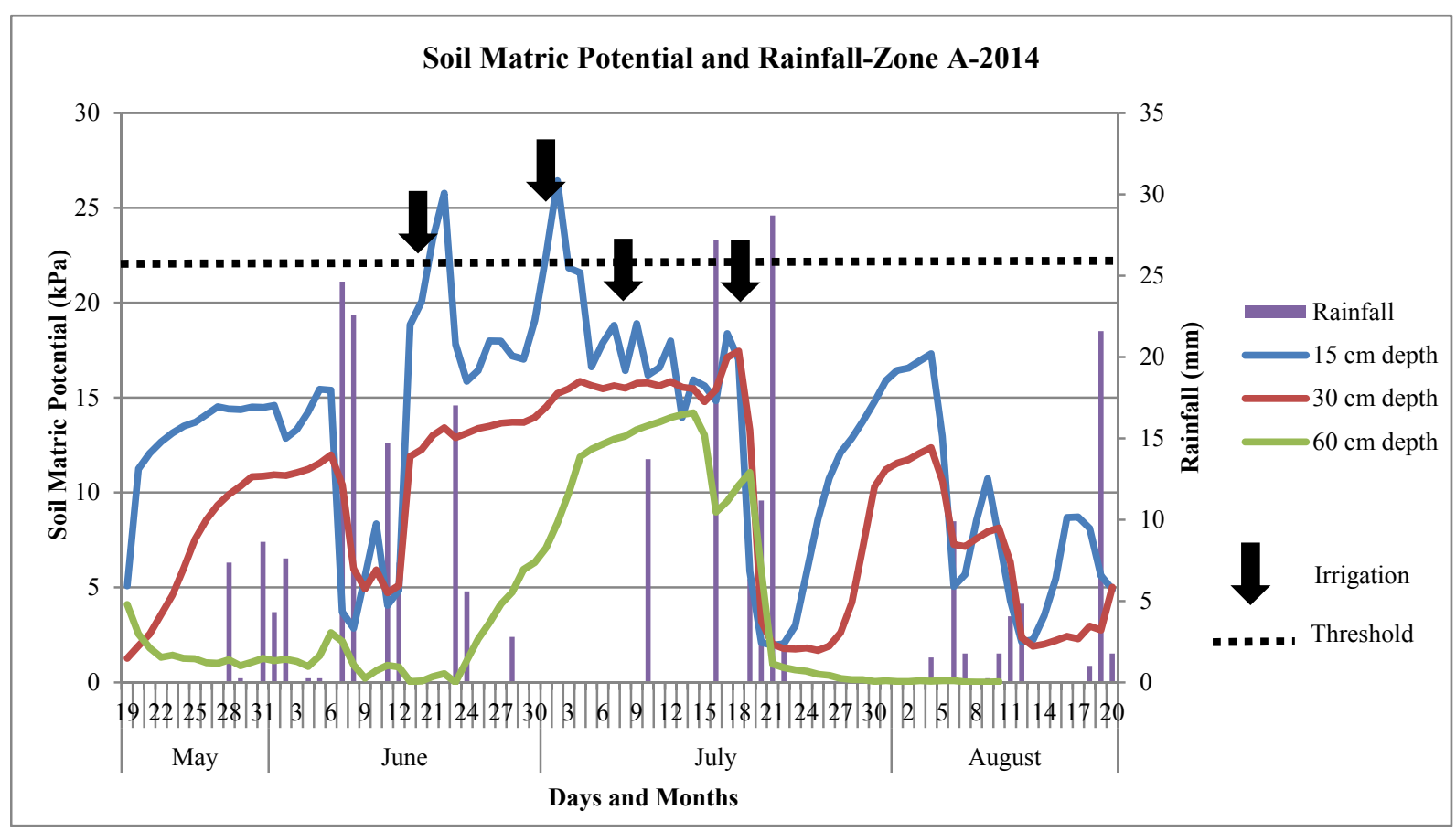

Figure 5. Changes in soil water potential provided by sensor 1 installed in zone A during the growing season of 2014 at EVSREC. The amount of irrigation referred in the black arrows were values between 15 and $25 \mathrm{~mm}$ to avoid runoff 


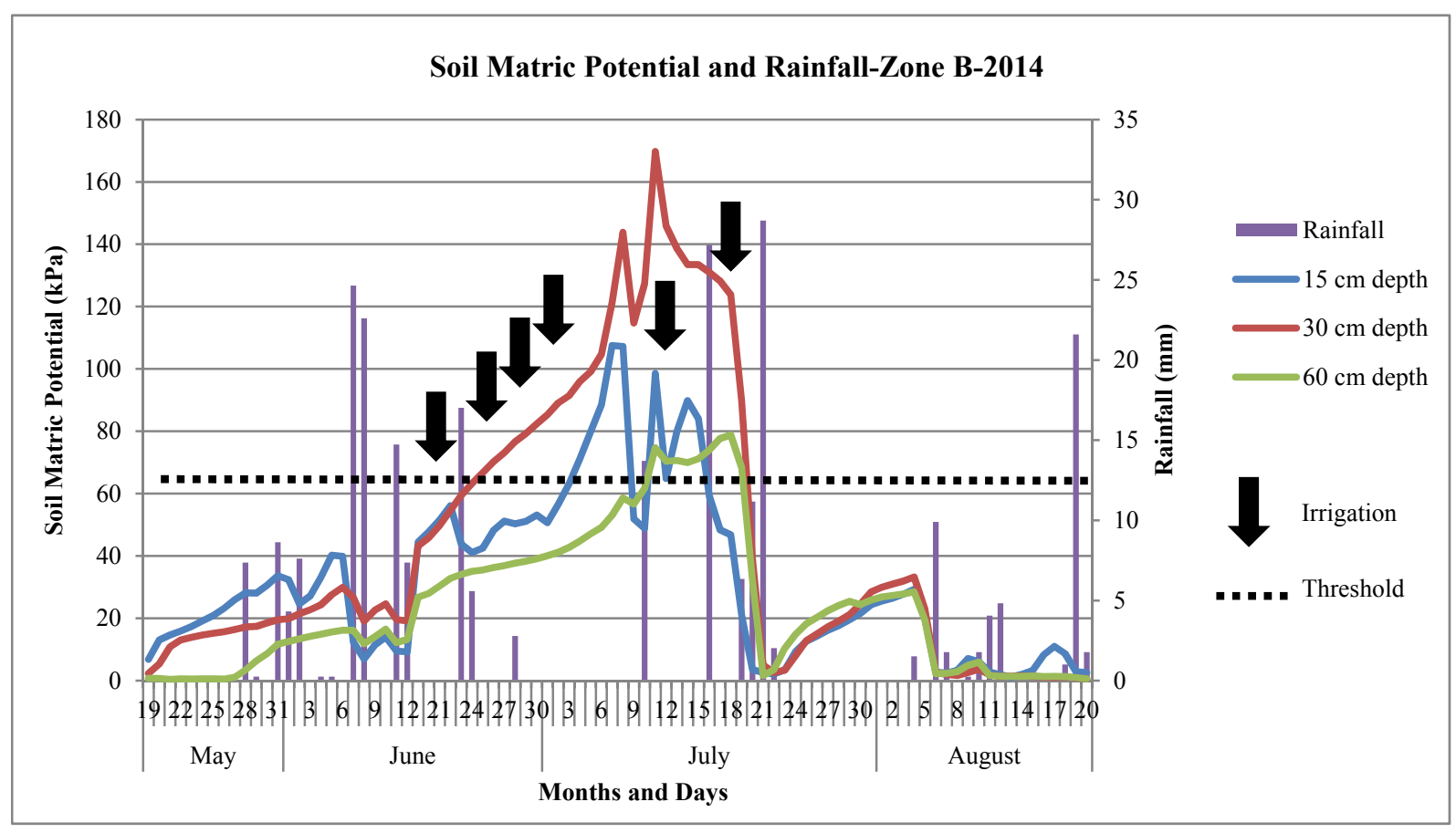

Figure 6. Changes in soil water Potential provided by sensor installed in zone B during the growing season of 2014 at EVSREC. The amount of irrigation referred in the black arrows were values between 15 and $25 \mathrm{~mm}$ to avoid runoff.

During the 2015 growing season, sensors placed in zone A indicated that irrigation event was initiated when one or all depths approached the threshold $(55 \mathrm{kPa})$. In some cases, for instance in July $27^{\text {th }}$ the threshold was approached however the irrigation was not necessary because the rainfall brought the tension to low values. Furthermore in the end of July the sensor located in the $60 \mathrm{~cm}$ depth started to present malfunction because the values were increasing quickly and it did not follow the trend of the others depths $(15$ and $30 \mathrm{~cm}$ ) (Figure 7). In zone B, the irrigation was triggered when SMP approached the irrigation threshold $(80 \mathrm{kPa})$. At the end of July sensors indicated high SMP and irrigation was not enough to decrease it. However, a period of frequent and high amount of rain decreased the values (Figure 8). 


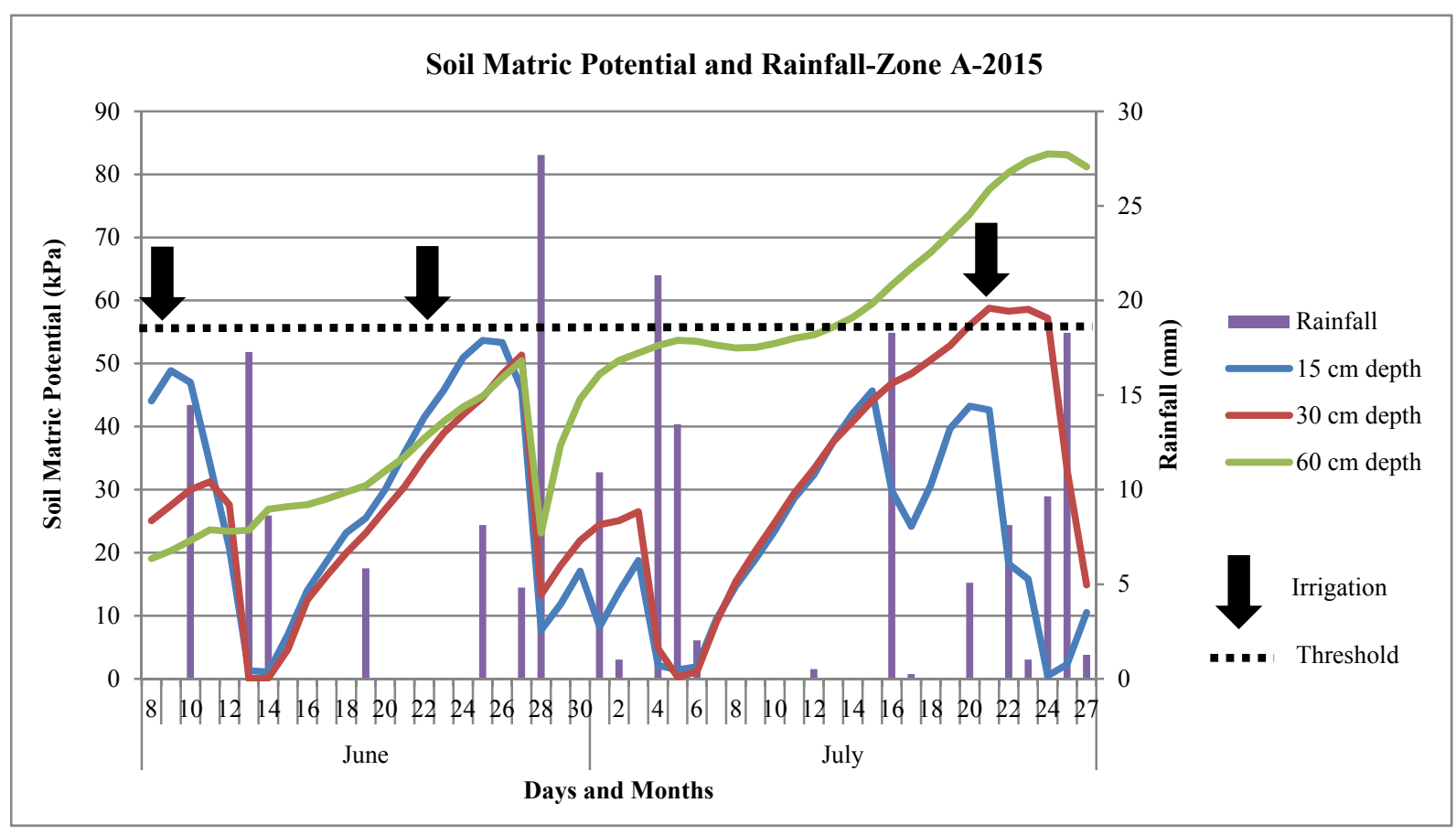

Figure 7. Changes in soil water Potential provided by sensor installed in zone A during the growing season of 2015 at EVSREC. The amount of irrigation referred in the black arrows were values between 15 and $25 \mathrm{~mm}$ to avoid runoff

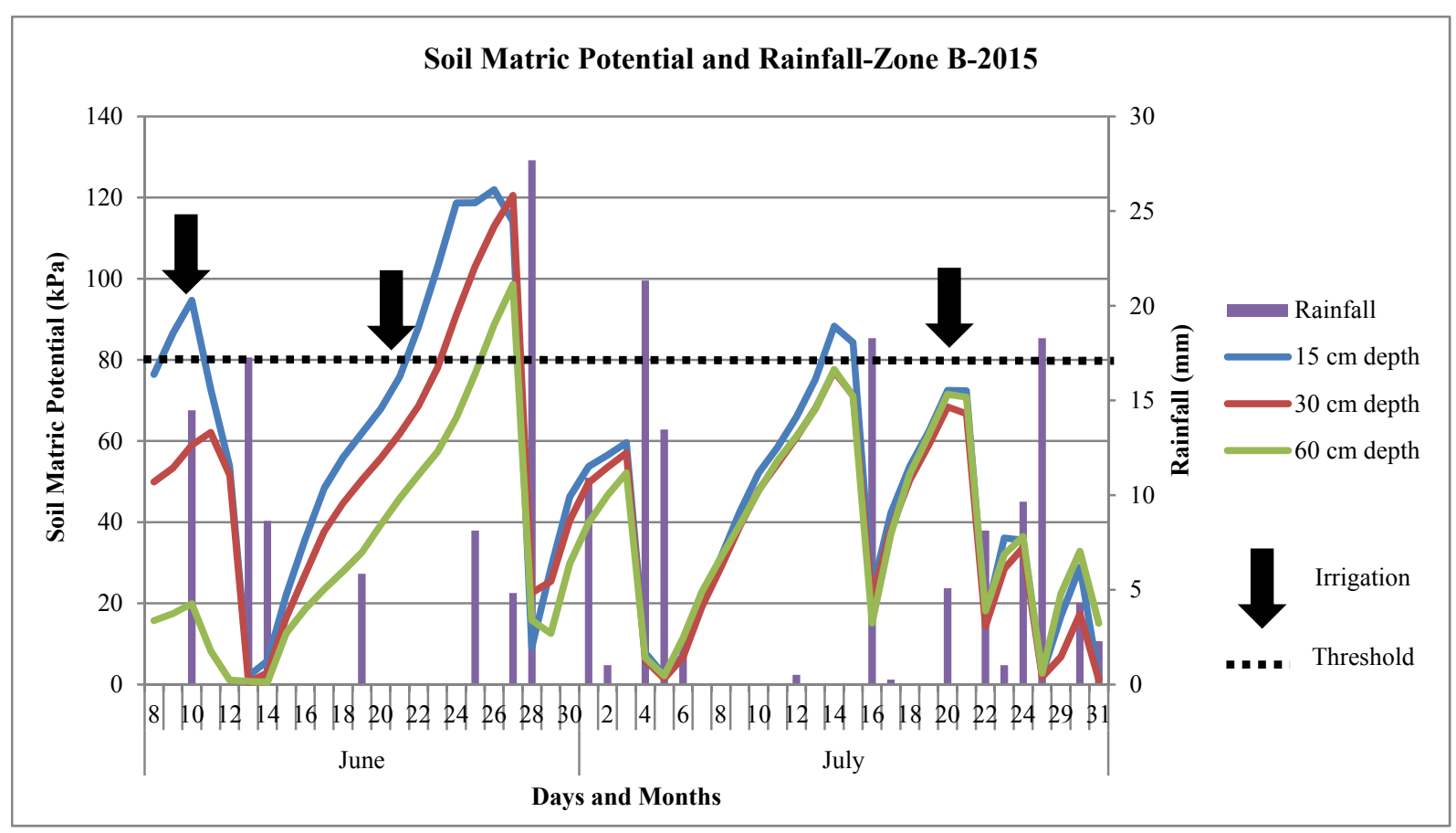

Figure 8. Changes in soil water Potential provided by sensor installed in zone B during the growing season of 2015 at EVSREC. The amount of irrigation referred in the black arrows were values between 15 and $25 \mathrm{~mm}$ to avoid runoff 


\subsection{Grain Yield Differences Between Irrigation Strategies}

In 2014, grain yield from the two irrigation methods, Checkbook and Sensor-based, was analyzed independently by zone. In zone A, there were statistically significant grain yield differences between the two irrigation methods, with Checkbook plots exhibiting higher yield than Sensor-based plots: $10181 \mathrm{~kg} \mathrm{ha}^{-1}$ and $9696 \mathrm{~kg} \mathrm{ha}^{-1}$, respectively (Table 6). The higher yield for the Checkbook plots could be associated with higher irrigation rate applied, $148 \mathrm{~mm}$ more, compared with the Sensor-based plots in zone A. On the other hand, grain yield differences in zone B were not significant between irrigation methods. However, Sensor-based plots out yielded Checkbook plots, with $9673 \mathrm{~kg} \mathrm{ha}^{-1}$ and $9584 \mathrm{~kg} \mathrm{ha}^{-1}$, respectively. Even though irrigation amount applied in the Sensor-based $(91 \mathrm{~mm})$ was lower than Checkbook $(193 \mathrm{~mm})$, there were no significant yield differences (Table 6). Therefore, it suggests that the Sensor-based method was a promising strategy for this zone.

Table 6. Grain yield, irrigation water applied, rainfall, water savings, water productivity and increase of water productivity during the growing season of 2014 at EVSREC

\begin{tabular}{|c|c|c|c|c|c|c|c|c|c|c|}
\hline \multirow[t]{2}{*}{ Zone } & \multirow[t]{2}{*}{ Treatment } & Grain yield & \multicolumn{2}{|c|}{$\begin{array}{l}\text { Irrigation } \\
\text { water applied }\end{array}$} & \multicolumn{2}{|l|}{ Rainfall } & \multicolumn{2}{|c|}{ Water save } & \multirow{2}{*}{$\begin{array}{l}\text { Water } \\
\text { Productivity }\end{array}$} & \multirow{2}{*}{$\begin{array}{l}\begin{array}{l}\text { Increase } \\
\text { of Water } \\
\text { Productivity }\end{array} \\
----\% \text {---- }\end{array}$} \\
\hline & & -- kg/ha $\neq--$ & -- mm -- & $--\mathrm{m}^{3} / \mathrm{ha}--$ & -- mm -- & $--\mathrm{m}^{3} / \mathrm{ha}--$ & -- mm -- & -- \% -- & & \\
\hline \multirow{2}{*}{ A } & Checkbook & 10180 a & 193 & 1930 & 613 & 6130 & 0 & 0 & 1.26 & 6.22 \\
\hline & Sensor & $9696 \mathrm{~b}$ & 45 & 450 & 613 & 6130 & 148 & 76 & 1.47 & 23.92 \\
\hline \multirow{2}{*}{ B } & Checkbook & $9584 \mathrm{a}$ & 193 & 1930 & 613 & 6130 & 0 & 0 & 1.19 & 0.00 \\
\hline & Sensor & $9674 \mathrm{a}$ & 91 & 910 & 613 & 6130 & 102 & 53 & 1.37 & 15.56 \\
\hline
\end{tabular}

Note. ₹ Statistical analysis (t-test) compared the two treatments (Checkbook and Sensor) within zone and not between zones; $\S$ Water Productivity $=$ Grain yield/Total water applied (Irrigation + Rainfall $)$.

In 2015, the Type III test of fixed effects indicated that grain yield was significant different for Irrigation and Interaction (Zone $\times$ Irrigation) (Table 7). The Sensor-based method in zone A and Checkbook method in zone B exhibited the highest grain yield: $13597 \mathrm{~kg} \mathrm{ha}^{-1}$ and $13417 \mathrm{~kg} \mathrm{ha}^{-1}$, respectively. The lowest grain yield, $11659 \mathrm{~kg}$ $\mathrm{ha}^{-1}$, was recorded in the Sensor-based plots located in zone B (Table 8). There were no significant grain yield differences between zone A and zone B when data from the Checkbook plots was analyzed. In contrast, there were significant grain yield differences between zones when data from the Sensor-based irrigation plots were analyzed. The Sensor-based method produced a grain yield of $13597 \mathrm{~kg} \mathrm{ha}^{-1}$ in zone A and $11659 \mathrm{~kg} \mathrm{ha}^{-1}$ in zone $\mathrm{B}$, although both zones received the same amount of irrigation. However, zone B should have held more water because this zone had a higher clay percentage. Therefore, applying the same amount of irrigation to both zones could oversaturate the soil in zone B, decreasing yield. Ponnamperuma (1984) stated that oversaturated areas are usually characterized by the absence of $\mathrm{O}_{2}$ and a lower amount of fertilizer. Therefore, the over-irrigation may occur in this zone and it could affect the grain yield. In zone A during 2015 growing season the implementation of the Sensor-based irrigation method showed positive results in terms of grain yield and water savings because when compared with the Checkbook method, the irrigation amount was lower but the yield was higher.

Table 7. Type III test of fixed effects of grain yield during the growing season of 2015 at EVSREC

\begin{tabular}{ll}
\hline Sources of Variation & Grain Yield \\
\hline Zone & $0.30^{*}$ \\
Irrigation & $<.0001$ \\
Zone x Irrigation & $<.0001$ \\
\hline
\end{tabular}

Note. * P-values-Significant at 0.05 probability level. 
Table 8. Grain yield, irrigation water applied, rainfall, water saving, water productivity and increase of water productivity during the growing season of 2015 at EVSREC.

\begin{tabular}{|c|c|c|c|c|c|c|c|c|c|c|}
\hline \multirow[t]{2}{*}{ Zone } & \multirow[t]{2}{*}{ Treatment } & Grain yield & \multicolumn{2}{|c|}{$\begin{array}{l}\text { Irrigation } \\
\text { water applied }\end{array}$} & \multicolumn{2}{|l|}{ Rainfall } & \multicolumn{2}{|c|}{ Water save } & \multirow{2}{*}{$\begin{array}{l}\text { Water } \\
\text { Productivity } \\
--\mathrm{kg} / \mathrm{m}^{3} \neq--\end{array}$} & $\begin{array}{l}\text { Increase } \\
\text { of Water } \\
\text { Productivity }\end{array}$ \\
\hline & & -- kg/ha -- & -- mm -- & $--\mathrm{m}^{3} / \mathrm{ha}--$ & -- mm -- & $--\mathrm{m}^{3} / \mathrm{ha}--$ & -- mm -- & -- \% -- & & ----- \% ---- \\
\hline \multirow{2}{*}{ A } & Checkbook & $12674 \mathrm{bc}$ & 121 & 1210 & 623 & 6230 & 0 & 0 & 1.70 & 1.25 \\
\hline & Sensor & $13597 \mathrm{a}$ & 70 & 700 & 623 & 6230 & 51 & 42 & 1.96 & 16.62 \\
\hline \multirow{2}{*}{ B } & Checkbook & $13417 \mathrm{ba}$ & 121 & 1210 & 623 & 6230 & 0 & 0 & 1.80 & 7.19 \\
\hline & Sensor & $11659 \mathrm{c}$ & 70 & 700 & 623 & 6230 & 51 & 42 & 1.68 & 0 \\
\hline
\end{tabular}

Note. ₹ Statistical analysis compared the two treatments (Checkbook and Sensor) within zone and between zones; $\S$ Water Productivity $=$ Grain yield/Total water applied (Irrigation + Rainfall).

\subsection{Water Productivity}

Increasing productivity of water in corn can be achieved by producing more corn yield with the same amount of water resources or decrease the amount of water and maintain the corn yield. In 2014, greater water productivity (WP) values were recorded for the Sensor-based irrigation plots, $1.37 \mathrm{~kg} \mathrm{~m}^{3}$ and $1.47 \mathrm{~kg} \mathrm{~m}^{3}$ in zones A and B, respectively. The use of the Checkbook method resulted on WP values of $1.26 \mathrm{~kg} \mathrm{~m}^{3}$ and $1.19 \mathrm{~kg} \mathrm{~m}^{3}$ for zone A and B, respectively (Table 6). Several irrigation experiments involving different irrigation levels showed that deficit irrigation can produce higher WP than full irrigation (Ali, Hoque, Hassan, \& Khair, 2007; Sarwar \& Perry, 2002). In this study the Sensor-based irrigation treatment could be considered as deficit irrigation because the irrigation trigger was set based on a percent depletion of plant available water, 35\% depletion, and then, received less water during the growing season. For instance, irrigation studies found that $2 / 3$ of full irrigation can increase water productivity by $19 \%$ in wheat and $8 \%$ for corn (Howell, Schneider, \& Evett, 1997; Schneider \& Howell, 1997). In the case of the 2014 growing season, the lowest WP value occurred when the Checkbook method was implemented in zone B. As of the Checkbook method, the same irrigation amount was applied on both zones; therefore, the differences in WP were associated with the corn grain yield response to irrigation and soil water holding characteristics between zones. The Sensor-based treatment tested on zone A, the zone with much greater sand content than zone B, showed greater water savings and increase of WP, $76 \%$ and $24 \%$, respectively. These values showed that sensors performed well in this zone because the Checkbook method did not result in water savings (Table 6).

In 2015, the greatest WP value was observed when the Sensor-based irrigation treatment was tested on zone A, the zone with a lighter soil texture in the shallow layers compared to zone B, which can be explained by less irrigation water applied (Table 8). Contrasting with the results in zone A, application of this method on zone B resulted in the lowest WP. This can be explained because of the low yield recorded where this method was implemented compared to yield from the Checkbook plots. Overall, water savings of $42 \%$ were recorded on both zones when the Sensor-based method was tested (Table 8).

\subsection{Economic Analysis}

In 2014, the greatest total profit per ha, $\$ 1382$, was observed when the Checkbook treatment was implemented on zone A, the zone with much lighter soil texture compared to zone B (Table 9). When the same irrigation scheduling method was evaluated on zone B, a zone with much heavier soil texture with respect to zone A, the lowest total profit value was recorded. When the average for profit by irrigation method was calculated, a profit of $\$ 1351$ resulted from use of the Sensor-based treatment compared to a lower profit, $\$ 1339$, from the use of the checkbook method. In general, total average profit differences between irrigation management were relatively small $(0.8 \%)$. 
Table 9. Grain yield, total income per hectare, total irrigation water applied, total irrigation cost, total profit per hectare and profit difference during the 2014 growing season at EVSREC

\begin{tabular}{llllllll}
\hline Zone & Treatment & $\begin{array}{l}\text { Grain yield } \\
(\mathrm{kg} / \mathrm{ha})\end{array}$ & $\begin{array}{l}\text { Total Income } \\
\text { per ha }(\$) \ddagger\end{array}$ & $\begin{array}{l}\text { Total Irrigation } \\
\text { Water Applied }(\mathrm{mm})\end{array}$ & $\begin{array}{l}\text { Total Irrigation Cost } \\
(\$ \text { per mm-ha) } \S\end{array}$ & $\begin{array}{l}\text { Total Profit } \\
\text { per ha }(\$)\end{array}$ & $\begin{array}{l}\text { Profit Difference } \\
(\%)\end{array}$ \\
\hline \multirow{2}{*}{ A } & Checkbook & 10180 & 1442.8 & 193 & 60.8 & 1382.0 & 6.5 \\
\hdashline & Sensor & 9696 & 1374.2 & 45 & 14.2 & 1360.1 & 4.8 \\
\hline \multirow{2}{*}{ B } & Checkbook & 9584 & 1358.4 & 193 & 60.8 & 1297.5 & 0.0 \\
& Sensor & 9674 & 1371.1 & 91 & 28.7 & 1342.4 & 3.5 \\
\hline
\end{tabular}

Note. ₹ Total income per ha $=$ grain yield $/ 25.4 \times \$ 3.60($ corn grain price $(\mathrm{bu}) ; \S$ Total irrigation cost $=$ total irrigation water applied $\times \$ 0.3151$ (price of $1 \mathrm{~mm}$ per ha in Alabama); $\uparrow$ Total Profit per ha $=$ total income per ha - total irrigation cost.

In 2015, the greatest total profit per ha, $\$ 1905$, was observed when the Sensor-based treatment was implemented on zone A, the zone with much lighter soil texture compared to zone B. On the other hand, the Sensor-based treatment was evaluated on zone B and the lowest total profit (\$1630) was observed (Table 10). When the average for profit by irrigation method was calculated, a profit of $\$ 1810$ resulted from the use of the Checkbook method compared $\$ 1767$, from use of the Sensor-based method and these differences were $2.4 \%$.

Table 10. Grain yield, total income per hectare, total irrigation water applied, total irrigation cost, total profit per hectare and profit difference during the 2015 growing season at EVSREC

\begin{tabular}{|c|c|c|c|c|c|c|c|}
\hline Zone & Treatment & $\begin{array}{l}\text { Grain yield } \\
(\mathrm{kg} / \mathrm{ha})\end{array}$ & $\begin{array}{l}\text { Total Income } \\
\text { per ha }(\$) \ddagger\end{array}$ & $\begin{array}{l}\text { Total Irrigation } \\
\text { Water Applied (mm) }\end{array}$ & $\begin{array}{l}\text { Total Irrigation Cost } \\
\text { (\$ per mm-ha) } \S\end{array}$ & $\begin{array}{l}\text { Total Profit } \\
\text { per ha }(\$)\end{array}$ & $\begin{array}{l}\text { Profit Difference } \\
(\%)\end{array}$ \\
\hline \multirow{2}{*}{ A } & Checkbook & 12674 & 1796.3 & 121 & 38.1 & 1758.2 & 7.8 \\
\hline & Sensor & 13597 & 1927.1 & 70 & 22.1 & 1905.1 & 16.8 \\
\hline \multirow{2}{*}{ B } & Checkbook & 13417 & 1901.6 & 121 & 38.1 & 1863.5 & 14.3 \\
\hline & Sensor & 11659 & 1652.5 & 70 & 22.1 & 1630.4 & 0.0 \\
\hline
\end{tabular}

Note. ₹ Total income per ha $=$ grain yield $/ 25.4 \times \$ 3.60($ corn grain price $(\mathrm{bu})) ; \S$ Total irrigation cost $=$ total irrigation water applied $\times \$ 0.3151$ (price of $1 \mathrm{~mm}$ per ha in Alabama); $\uparrow$ Total Profit per ha $=$ total income per ha - total irrigation cost.

\section{Conclusion}

This on-farm study conducted over two growing seasons provided a representation of weather, soil and management conditions under which corn is produced in Alabama. Since this study was conducted on commercial-scale fields, the microclimate, soil water balance, and management components differed substantially from small-plot studies. Grain yield in 2014 ranged from $9584 \mathrm{~kg} \mathrm{ha}^{-1}$ to $10180 \mathrm{~kg} \mathrm{ha}^{-1}$; however, in 2015, grain yield ranged from $11659 \mathrm{~kg} \mathrm{ha}^{-1}$ to $13597 \mathrm{~kg} \mathrm{ha}^{-1}$. Furthermore, the 2014 season might have presented yield values lower than the 2015 season because southern corn rust disease infested a large area of corn fields planted in the state and it caused yield losses during the 2014 growing season. Summarizing results of both growing seasons, the Sensor-based irrigation scheduling method performed well considering that was the first time testing this technology in Alabama. Overall, the Sensor-based irrigation achieved similar values for total profit per hectare when compared to the Checkbook method. The Sensor-based irrigation saved water for producer and produced a similar financial return, it might be due that fact that the sensors were providing more accurate data in terms of water requirements by corn plants. Furthermore, reducing water waste minimizes risks of leaching, runoff, and crop diseases.

\section{Recommendation for Future Research}

Further research addressing the SMP corresponding the FC for the various soils in Alabama is required because a minor change in this tension can cause a great difference in the PAW values. Therefore, more accurate values of PAW will represent a more realistic volumetric water content available for plants. Consequently, the water depletion selected as irrigation threshold will be more trustful. Moreover, the evaluation of different irrigation threshold values is important, because in this study we select $35 \%$ of PAW, but higher or lower, threshold values would likely produce different results. Additional years of research can potentially improve the experience to manage soil moisture sensors and increase long-term impacts. 


\section{Acknowledgements}

The authors are grateful to the Department of Crop, Soil and Environmental Sciences of Auburn University and E. V. Smith Research Center.

\section{References}

Aina, P. O., \& Periaswamy, S. P. (1985). Estimating available water-holding capacity of western Nigerian soils from soil texture and bulk density, using core and sieved samples Soil Science, 140(1), 55-58. https://doi.org/10.1097/00010694-198507000-00007

Ali, M. H., Hoque, M. R., Hassan, A. A., \& Khair, A. (2007). Effects of deficit irrigation on yield, water productivity, and economic returns of wheat. Agricultural Water Management, 92(3), 151-161. https://doi.org/10.1016/j.agwat.2007.05.010

Armstrong, C., Ligon, J., \& Thomson, S. (1985). Calibration of Watermark Model 200 soil moisture sensor. Microfiche collection.

Bausch, W., \& Bernard, T. (1996). In C. R. Camp, E. J. Sadler, \& R. E. Yoder (Eds.), Validity of the Watermark sensor as a soil moisture measuring device. Paper presented at the Proc. of the Intl. Conf. Evapotranspiration and Irrigation Scheduling. St. Joseph, MI: ASAE.

Broner, I. (1989). Irrigation scheduling: The water-balance approach. Service in action (4.707).

Chanzy, A., Chadoeuf, J., Gaudu, J. C., Mohrath, D., Richard, G., \& Bruckler, L. (1998). Soil moisture monitoring at the field scale using automatic capacitance probes. European Journal of Soil Science, 49(4), 637-648. https://doi.org/10.1046/j.1365-2389.1998.4940637.x

Corwin, D. L., \& Lesch, S. M. (2003). Application of soil electrical conductivity to precision agriculture. Agronomy Journal, 95(3), 455-471. https://doi.org/10.2134/agronj2003.4550

Dougherty, M., AbdelGadir, A., Fulton, J. P., Burmester, C., Curtis, L. M., \& Tyson, T. (2008). Sprinkler irrigation for site-specific, precision management of cotton. Research Report Series.

Duncan, H. A. (2012). Locating the variability of soil water holding capacity and understanding its effects on deficit irrigation and cotton lint yield.

Evans, R. G., Han, S., Schneider, S. M., \& Kroeger, M. W. (1996). Precision center pivot irrigation for efficient use of water and nitrogen. Proceedings of the 3rd International Conference on Precision Agriculture (pp. 75-84). https://doi.org/10.2134/1996.precisionagproc3.c8

Evans, R. G., LaRue, J., Stone, K. C., \& King, B. A. (2013). Adoption of site-specific variable rate sprinkler irrigation systems. Irrigation Science, 31(4), 871-887. https://doi.org/10.1007/s00271-012-0365-X

Evett, S. R., \& Parkin, G. W. (2005). Advances in soil water content sensing: The continuing maturation of technology and theory. Vadose Zone Journal, 4(4), 986-991. https://doi.org/10.2136/vzj2005.0099

Fridgen, J. J., Kitchen, N. R., Sudduth, K. A., Drummond, S. T., Wiebold, W. J., \& Fraisse, C. W. (2004). Management Zone Analyst (MZA). Agronomy Journal, 96(1), 100-108. https://doi.org/10.2134/agronj 2004.0100

Hedley, C. B., \& Yule, I. J. (2009). Soil water status mapping and two variable-rate irrigation scenarios. Precision Agriculture, 10(4), 342-355. https://doi.org/10.1007/s11119-009-9119-Z

Howell, T. A., Schneider, A., \& Evett, S. (1997). Subsurface and surface microirrigation of corn-Southern High Plains. Transactions of the ASAE, 40(3), 635-641. https://doi.org/10.13031/2013.21322

Irmak, S., Burgert, M. J., Yang, H. S., Cassman, K. G., Walters, D. T., Rathje, W. R., ... Brunkhorst, K. J. (2012). Large-scale on-farm implementation of soil moisture-based irrigation management strategies for increasing maize water productivity. Transactions of the ASABE, 55(3), 881-894. https://doi.org/10.13031/ 2013.41521

Irmak, S., Rees, J. M., Zoubek, G. L., van DeWalle, B. S., Rathje, W. R., DeBuhr, R., ... Christiansen, A. P. (2010). Nebraska agricultural water management demonstration network: Integrating research and extension/outreach. Applied Engineering in Agriculture, 26(4), 599-613. https://doi.org/10.13031/2013. 32066

Jones, H. G. (2004). Irrigation scheduling: Advantages and pitfalls of plant-based methods. Journal of Experimental Botany, 55(407), 2427-2436. https://doi.org/10.1093/jxb/erh213 
Keswani, B., Mohapatra, A. G., Mohanty, A., Khanna, A., Rodrigues, J. J. P. C., Gupta, D., \& de Albuquerque, V. H. C. (2019). Adapting weather conditions based IoT enabled smart irrigation technique in precision agriculture mechanisms. Neural Computing and Applications, 31(1), 277-292. https://doi.org/10.1007/ s00521-018-3737-1

Kirda, C. (2002). Deficit irrigation scheduling based on plant growth stages showing water stress tolerance. Deficit Irrigation Practices, Water Reports, 22(102). Food and Agricultural Organization of the United Nations, Rome, Italy.

Kizito, F., Campbell, C. S., Campbell, G. S., Cobos, D. R., Teare, B. L., Carter, B., \& Hopmans, J. W. (2008). Frequency, electrical conductivity and temperature analysis of a low-cost capacitance soil moisture sensor. Journal of Hydrology, 352(3), 367-378. https://doi.org/10.1016/j.jhydrol.2008.01.021

Lee, D. H., Harris, G. H., Harrison, K., Prostko, E. P., Buntin, G. D., Kemerait, B., ... Smith, A. (2014). A guide to corn production in Georgia 2014.

Lundstrom, D. R., \& Stegman, E. C. (1988). Irrigation scheduling by the checkbook method.

Mitchell, A. R., \& Shock, C. C. (1996). In C. R. Camp, E. J. Sadler, \& R. E. Yoder (Eds.), A Watermark datalogging system for ET measurement. Paper presented at the Proc. of the Intl. Conf. Evapotranspiration and Irrigation Scheduling. St. Joseph, MI: ASAE.

Molden, D. (1997). Accounting for water use and productivity. IWMI.

Molden, D., Oweis, T. Y., Pasquale, S., Kijne, J. W., Hanjra, M. A., Bindraban, P. S., ... Farahani, H. (2007). Pathways for increasing agricultural water productivity. Retrieved from https://cgspace.cgiar.org/handle/ 10568/36882

Munir, M. S., Bajwa, I. S., Naeem, M. A., \& Ramzan, B. (2018). Design and implementation of an IoT system for smart energy consumption and smart irrigation in tunnel farming. Energies, 11(12), 3427. https://doi.org/10.3390/en11123427

NASS, U. (2007). Census of Agriculture: United States, Summary and State Data (Report AC-07-A-51). Washington, DC: USDA.

NASS, U. (2016). Quick stats. USDA-NASS, Washington, DC.

Pan, L., Adamchuk, V. I., Martin, D. L., Schroeder, M. A., \& Ferguson, R. B. (2013). Analysis of soil water availability by integrating spatial and temporal sensor-based data. Precision Agriculture, 14(4), 414-433. https://doi.org/10.1007/s11119-013-9305-x

Ponnamperuma, F. (1984). Effects of flooding on soils. Flooding and Plant Growth, 9-45. https://doi.org/ 10.1016/B978-0-12-424120-6.50007-9

Ray, D. K., Mueller, N. D., West, P. C., \& Foley, J. A. (2013). Yield trends are insufficient to double global crop production by 2050. PloS ONE, 8(6), e66428. https://doi.org/10.1371/journal.pone.0066428

Richards, L., \& Weaver, L. (1944). Moisture retention by some irrigated soils as related to soil moisture tension. Journal of Agricultural Research, 69(6), 215-235.

Rosegrant, M. W., Ringler, C., \& Zhu, T. J. (2009). Water for Agriculture: Maintaining Food Security under Growing Scarcity. Annual Review of Environment and Resources (Vol. 34, pp. 205-222). https://doi.org/ 10.1146/annurev.environ.030308.090351

Sadler, E. J., Evans, R. G., Stone, K. C., \& Camp, C. R. (2005). Opportunities for conservation with precision irrigation. Journal of Soil and Water Conservation, 60(6), 371-378.

Sarwar, A., \& Perry, C. (2002). Increasing water productivity through deficit irrigation: evidence from the Indus plains of Pakistan. Irrigation and Drainage, 51(1), 87-92. https://doi.org/10.1002/ird.39

Schneider, A., \& Howell, T. (1997). Methods, amounts, and timing of sprinkler irrigation for winter wheat. Transactions of the ASAE, 40(1), 137-142. https://doi.org/10.13031/2013.21258

Seyfried, M. S., \& Murdock, M. D. (2004). Measurement of soil water content with a 50-MHz soil dielectric sensor. Soil Science Society of America Journal, 68(2), 394-403. https://doi.org/10.2136/sssaj2004.3940

Thomson, S. J., Younos, T., \& Wood, K. (1996). Evaluation of Calibration Equations and Application Methods for the Watermark ${ }^{\circledR}$ Granular Matrix Soil Moisture Sensor. Applied Engineering in Agriculture, 12(1), 99-103. https://doi.org/10.13031/2013.25444 
United Nations, N. Y. (2001). World population prospects (The 2000 Revision).

USDA. (2011). Web soil survey. Retrieved from http://websoilsurvey.nrcs.usda.gov

Van Genuchten, M. T. (1980). A closed-form equation for predicting the hydraulic conductivity of unsaturated soils. Soil Science Society of America Journal, 44(5), 892-898. https://doi.org/10.2136/sssaj1980.0361599 $5004400050002 \mathrm{x}$

Vaux Jr, H. J., \& Pruitt, W. O. (1983). Crop-water production functions. Advances in irrigation (Vol. 2, pp. 61-97). Elsevier. https://doi.org/10.1016/B978-0-12-024302-0.50009-6

Vellidis, G., Tucker, M., Perry, C., Kvien, C., \& Bednarz, C. (2008). A real-time wireless smart sensor array for scheduling irrigation. Computers and Electronics in Agriculture, 61(1), 44-50. https://doi.org/10.1016/ j.compag.2007.05.009

Williams, B., \& Hoey, D. (1987). The use of electromagnetic induction to detect the spatial variability of the salt and clay contents of soils. Soil Research, 25(1), 21-27. https://doi.org/10.1071/SR9870021

Wright, J., \& Bergsrud, F. (1991). Irrigation scheduling: Checkbook method. Bulletin AG-FO-13322-C. St. Paul, Minn.: Minn. Ext. Serv.

Yao, T., Wierenga, P. J., Graham, A. R., \& Neuman, S. P. (2004). Neutron probe calibration in a vertically stratified vadose zone. Vadose Zone Journal, 3(4), 1400-1406. https://doi.org/10.2136/vzj2004.1400

Zwart, S. J., \& Bastiaanssen, W. G. M. (2004). Review of measured crop water productivity values for irrigated wheat, rice, cotton and maize. Agricultural Water Management, 69(2), 115-133. https://doi.org/10.1016/ j.agwat.2004.04.007

\section{Copyrights}

Copyright for this article is retained by the author(s), with first publication rights granted to the journal.

This is an open-access article distributed under the terms and conditions of the Creative Commons Attribution license (http://creativecommons.org/licenses/by/4.0/). 